\title{
PENERAPAN PSAK NO. 45 REVISI TAHUN 2015 PADA YAYASAN MADRASAH IBTIDAIYAH BAITUL MAKMUR KOTA KOTAMOBAGU
}

\author{
Aldiansyah $^{1}$, Linda Lambey $^{2}$ \\ ${ }^{1}$ Pendidikan Profesi Akuntansi, Fakultas Ekonomi dan Bisnis, Universitas Sam Ratulangi, J1. Kampus Bahu, \\ Manado, 95115, Indonesia \\ ${ }^{2}$ Jurusan Akuntansi, Fakultas Ekonomi dan Bisnis, Universitas Sam Ratulangi, Jl. Kampus Bahu, Manado, \\ 95115, Indonesia \\ E-mail : aldiansyah_sugeha@yahoo.com
}

\begin{abstract}
Along with the times, now a non-profit organization has been growing rapidly, for example a foundation engaged in educational, religious, health and others. Kotamobagu State Islamic Elementary School is an example of a foundation that is engaged in the field of education are categorized into non-profit organizations because it has the resources coming from student fees and parental contributions. As with any profit organizations, non-profit organizations also require knowledge of accounting to record expenses and revenues. In order to provide some form of responsibility and accountability to the community, the foundation is also required to prepare financial statements in accordance with the rules or standards that already exist. The purpose of this study was to determine the Financial Statements of Government Elementary School Baitul Makmur when applying PSAK No. 45. The method used is descriptive qualitative. Result shows that Government Elementary School have made a financial statement is still as simple as cash receipt book, cash expenditure book, the book recapitulation and did not make statements as set forth in PSAK No. 45.
\end{abstract}

Keywords : PSAK, Nonprofit, Financial Statement

\section{PENDAHULUAN}

Organisasi didirikan untuk mencapai tujuan yang telah ditetapkan. Berdasarkan tujuannya organisasi dibedakan atas organisasi berorientasi laba dan organisasi berorientasi non laba atau organisasi nirlaba. Menurut Sujarweni, (2015:185) bahwa organisasi nirlaba memperoleh sumber daya dari sumbangan para anggota dan para penyumbang lain yang tidak mengharapkan imbalan apapun dari organisasi tersebut. Salah satu contoh dari organisasi nirlaba adalah sebuah yayasan. Akuntansi dibutuhkan oleh yayasan, berkaitan dengan hal itu maka disusunlah Pernyataan Standar Akuntansi Keuangan (PSAK) No. 45 tentang Pelaporan Keuangan Entitas Nirlaba. Sesuai dengan PSAK tersebut, laporan keuangan organisasi nirlaba terdiri dari laporan posisi keuangan, laporan aktivitas, laporan arus kas, dan catatan atas laporan keuangan (Pontoh, 2013:3).

Madrasah Ibtidaiyah Baitul Makmur Kota Kotamobagu adalah sebuah organisasi nirlaba yang bergerak dalam bidang pendidikan. Dalam Islam Madrasah Ibtidaiyah ini sama dengan sekolah dasar yang berpedoman pada agama Islam atas proses belajar mengajarnya. Madrasah Ibtidaiyah ini menjadi sekolah favorit di Kota Kotamobagu. Tetapi dalam hal laporan keuangannya masih sangat sederhana dan membutuhkan perbaikan. Untuk itu penulis tertarik untuk mengetahui bagaimana pelaporan keuangan pada yayasan ini dan melakukan penelitian dengan judul "Penerapan PSAK No. 45 Revisi Tahun 2015 Pada Yayasan Madrasah Ibtidaiyah Baitul Makmur Kota Kotamobagu”. 


\section{TINJAUAN PUSTAKA}

\subsection{Konsep Akuntansi}

Menurut Reeve, James M., Warren, Carl S., Duchac, Jonathan E., Wahyuni, Ersa Tri., Soepriyanto, Gatot., Jusuf, Amir Abadi. \& Djakman, Chaerul D (2009:9), akuntansi (accounting) merupakan "suatu sistem informasi yang menyediakan laporan untuk para pemangku kepentingan mengenai aktivitas dan kondisi ekonomi perusahaan".

\subsection{Definisi Organisasi Nirlaba}

Menurut Mahsun Mohamad dkk, Organisasi nirlaba adalah organisasi yang dapat dimiliki pemerintah maupun dimiliki sektor swasta, tujuan utamanya tidak semata-mata untuk mendapatkan keuntungan.

\subsection{Ciri-ciri Organisasi Nirlaba}

Organisasi nirlaba atau organisasi yang tidak bertujuan memupuk keuntungan memiliki ciri-ciri yaitu : Sumber daya entitas,Menghasilkan barang/jasa tanpa bertujuan menumpuk laba, Tidak ada kepemilikan seperti lazimnya pada organisasi bisnis. Menurut Mahsun Mohamad dkk, karakteristik entitas nirlaba berbeda dengan entitas bisnis. Perbedaan utama yang mendasar terletak pada cara entitas nirlaba memperoleh sumber daya yang dibutuhkan untuk melakukan berbagai aktivitas operasinya. Entitas nirlaba memperoleh sumber daya dari pemberi sumber daya yang tidak mengharapkan pembayaran kembali atau manfaat ekonomi yang sebanding dengan jumlah sumber daya yang diberikan.

\subsection{PSAK No. 45 Akuntansi Organisasi Nirlaba}

Menurut IAI (20011 : 45) 4 (empat) laporan keuangan pada organisasi nirlaba meliputi : (1) Laporan Keuangan, (2) Laporan Aktivitas, (3) Laporan Kas dan (4) Catatan atas Laporan Keuangan. Tujuan laporan keuangan dalam organisasi nirlaba adalah untuk menyediakan informasi mengenai aktiva, kewajiban, dan aktiva bersih dan informasi mengenai hubungan di antara unsur-unsur tersebut pada waktu tertentu.

\subsection{Tujuan Laporan Keuangan Organisasi Nirlaba}

Dalam buku A Statement of Basic Accounting Theory (ASOBAT), seperti yang dikutip dan diterjemahkan oleh Harahap (2011:126), empat tujuan laporan keuangan yaitu Membuat keputusan yang menyangkut pengunaan kekayaan yang terbatas dan untuk mencapai tujuan, Mengarahkan dan mengontrol secara efektif Sumber Daya Manusia dan faktor produksi lainnya, Memelihara dan melaporkan pengamanan terhadap kekayaan, dan membantu fungsi dan pengawasan sosial.

\subsection{Pengertian dan Karakteristik Yayasan}

Pengertian/definisi yang dinyatakan dalam Pasal 1 butir 1 Undang-Undang Yayasan No. 28 Tahun 2004 atas perubahan Undang-Undang Yayasan No. 16 Tahun 2001 tentang Yayasan yaitu suatu Badan Hukum yang kekayaannya terdiri dari kekayaan yang dipisahkan untuk mencapai tujuan tertentu di bidang sosial, keagamaan, dan kemanusiaan.

\section{Penelitian Terdahulu}

\begin{tabular}{|c|c|c|c|c|c|c|c|}
\hline No & $\begin{array}{l}\text { Nama / } \\
\text { Tahun }\end{array}$ & Judul & Tujuan & Metode & Hasil & Persamaan & Perbedaan \\
\hline 1. & $\begin{array}{l}\text { Chenly } \\
\text { Ribka S. } \\
\text { Pontoh } \\
(2013)\end{array}$ & $\begin{array}{l}\text { Penerapan } \\
\text { Penyusunan } \\
\text { Laporan } \\
\text { Keuangan } \\
\text { Organisasi } \\
\text { Nirlaba } \\
\text { Berdasarkan } \\
\text { PSAK No. } \\
\text { 45 Pada } \\
\text { Gereja } \\
\text { Bukit }\end{array}$ & $\begin{array}{l}\text { Untuk } \\
\text { melihat } \\
\text { bagaimana } \\
\text { penerapan } \\
\text { laporan } \\
\text { keuangan } \\
\text { Gereja Bukit } \\
\text { Zaitun } \\
\text { Luwuk } \\
\text { Sulawesi } \\
\text { Tengah }\end{array}$ & KualitatifDeskriptif & $\begin{array}{l}\text { Gereja } \\
\text { Bukit } \\
\text { Zaitun } \\
\text { Luwuk } \\
\text { Belum } \\
\text { menerapkan } \\
\text { PSAK No } \\
45\end{array}$ & $\begin{array}{l}\text { Penerapan } \\
\text { PSAK No. } \\
45\end{array}$ & $\begin{array}{l}\text { Objek } \\
\text { Penelitian }\end{array}$ \\
\hline
\end{tabular}




\begin{tabular}{|c|c|c|c|c|c|c|c|}
\hline No & $\begin{array}{l}\text { Nama / } \\
\text { Tahun }\end{array}$ & Judul & Tujuan & Metode & Hasil & Persamaan & Perbedaan \\
\hline & & $\begin{array}{l}\text { Zaitun } \\
\text { Luwuk } \\
\text { Sulawesi } \\
\text { Tengah }\end{array}$ & $\begin{array}{l}\text { apakah telah } \\
\text { sesuai } \\
\text { dengan } \\
\text { PSAK No. } \\
45\end{array}$ & & & & \\
\hline 2. & $\begin{array}{l}\text { Melisa } \\
\text { Mamesah } \\
(2013)\end{array}$ & $\begin{array}{l}\text { Penerapan } \\
\text { PSAK No. } \\
45 \text { Pada } \\
\text { GMIM } \\
\text { Efrata } \\
\text { Sentrum } \\
\text { Sonder } \\
\text { Kaitannya } \\
\text { Dengan } \\
\text { Kualitas } \\
\text { Informasi } \\
\text { Laporan } \\
\text { Keuangan }\end{array}$ & $\begin{array}{l}\text { Untuk } \\
\text { Mengetahui } \\
\text { Apakah } \\
\text { GMIM } \\
\text { Efrata } \\
\text { Sentrum } \\
\text { Sonder sudah } \\
\text { menerapkan } \\
\text { PSAK No. } \\
\text { 45 Pada } \\
\text { Penyajian } \\
\text { Laporan } \\
\text { Keuangannya } \\
\text { dan Untuk } \\
\text { Mengetahui } \\
\text { Apakah } \\
\text { GMIM } \\
\text { Efrata } \\
\text { Sentrum } \\
\text { Sonder } \\
\text { Memiliki } \\
\text { Kualitas } \\
\text { Informasi } \\
\text { Laporan } \\
\text { Keuangan } \\
\text { Yang } \\
\text { Memenuhi } \\
\text { Syarat Dalam } \\
\text { Memberi } \\
\text { Penjelasan } \\
\text { Bagi Para } \\
\text { Pemakai } \\
\text { Laporan } \\
\text { Keuangan }\end{array}$ & KualitatifDeskriptif & $\begin{array}{l}\text { GMIM } \\
\text { Efrata } \\
\text { Sentrum } \\
\text { Sonder } \\
\text { belum } \\
\text { menerapkan } \\
\text { PSAK } \\
\text { No.45 }\end{array}$ & $\begin{array}{l}\text { Penerapan } \\
\text { PSAK No. } \\
45\end{array}$ & $\begin{array}{l}\text { Objek } \\
\text { Penelitian }\end{array}$ \\
\hline
\end{tabular}

\section{METODE PENELITIAN}

\subsection{Jenis Penelitian}

Penelitian ini adalah penelitian kualitatif yang menghasilkan penemuan penemuan yang tidak dapat dicapai dengan menggunakan prosedur prosedur statistik atau dengan cara kuantifikasi lainnya. Menurut Sugiyono (2010), jenis-jenis metode penelitian dikelompokkan berdasarkan, tujuan, dan tingkat kealamiahan (natural setting) obyek yang diteliti.

\subsection{Tempat dan Waktu Penelitian}

Penelitian ini dilakukan pada Madarah Ibtidaiyah Baitul Makmur Kota Kotamobagu yang berlokasi di Jalan Jend. Ahmad Yani No. 10 Kelurahan Kotamobagu, Kecamatan Kotamobagu Barat, Kota Kotamobagu, Provinsi Sulawesi Utara. Waktu penelitan sekitar 2 bulan.

\subsection{Jenis Data}

Penelitian ini ada dua jenis data yaitu data kuantitatif dan kualitatif. Menurut Kuncoro (2009:145), data kuantitatif adalah data yang diukur dalam suatu dan data kualitatif adalah data yang tidak dapat diukur dalam skala numerik. 


\subsection{Teknik Pengumpulan Data}

Teknik pengumpulan data yang digunakan yaitu wawancara, teknik rekaman, survey lapangan, dan studi kepustakaan.

\subsection{Metode Analisis}

Metode penelitian yang digunakan dalam penelitian ini adalah metode deskriptif kualitatif yang menurut I Made Winartha (2006:155) yaitu : "Metode analisis deskriptif kualitatif yaitu menganalisis, menggambarkan, dan meringkas berbagai kondisi, situasi ari berbagai data yang dikumpulkan berupa hasil wawacara atau pengamatan mengnai masalah yang diteliti yang terjadi di lapangan".

\section{HASIL ANALISIS DAN PEMBAHASAN}

\subsection{Hasil Penelitian}

Madrasah Ibtidaiyah Baitul Makmur Kota Kotamobagu ini berdiri pada 29 Juli 1998 adalah suatu lembaga pendidikan yang dibentuk sebagai upaya untuk turut mengambil bagian dalam melaksanakan tugas mempersiapkan generasi islam guna menjawab tantangan masa depan yang kian kompleks dan berat. Kemudian lahirlah dasar Visi yaitu "Terbina dalam akhlakul karimah, terdepan dalam prestasi”. Orang-orang yang pernah menjadi kepala yayasan ini yaitu antara lain Bapak Darsun Tunggali, Bapak Muktar Ganggai, Bapak Arkam Lahia, Ibu Suliati Mokodongan, dan yang masih memimpin hingga sekarang adalah Ibu Marwiyah Paputungan.

Laporan keuangan Madrasah Ibtidaiyah Baitul Makmur mengacu pada arahan pengurus Yayasan, ketetapan dari rapat bersama pengurus Madrasah, serta dari usul dan saran-saran yang diberikan oleh orang-orang tua murid. Sumber penerimaan dari Madrasah Ibtidaiyah sendiri berasal dari beberapa sumber yaitu terdiri dari Iuran Komite Siswa, Infaq, dan Bantuan Operasional Sekolah. Setiap penerimaan kas yang terjadi di Madrasah Ibtidaiyah akan dibuatkan bukti penerimaan kas berupa kartu iuran dan infaq, untuk dana BOS yang menjadi bukti penerimaan adalah slip penarikan uang dari Bank. Sama halnya dengan kas keluar, pihak Bendahara Yayasan akan mengeluarkan bukti kas keluar berupa kwitansi. Bendahara Yayasan kemudian akan menginput setiap bukti kas masuk dan keluar ini kedalam laporan kas umum. Berdasarkan pada Laporan Kas Umum yang dibuat oleh pihak Yayasan, kemudian akan direkap untuk menjadi Laporan Realisasi Anggaran.

Menurut IAI (2011 : 45) 4 (empat) laporan keuangan pada organisasi nirlaba meliputi: (1) Laporan Keuangan, (2) Laporan Aktivitas, (3) Laporan Kas dan (4) Catatan atas Laporan Keuangan. 
Tabel 1. Laporan Posisi Keuangan

\section{Madrasah Ibtidaiyah Baitul Makmur Kota Kotamobagu \\ Laporan Posisi Keuangan \\ Tahun Ajaran 2015/2016 \\ (dalam jutaan rupiah)}

\section{ASET}

Aset Lancar

Kas Dana Bos

Kas Infaq

Aset Tidak Lancar

Aset Tetap setelah dikurangi Akum.

Penyusutan (Catatan D)

\section{Jumlah Aset}

LIABILITAS

Liabilitas Jangka Pendek

Liabilitas Jangka Panjang

Jumlah Liabilitas

ASET NETO

Tidak Terikat

Terikat Temporer (Catatan B)

Terikat Permanen

Jumlah Aset Neto

Sumber: Data Olahan, 2016

Tabel 1 terdapat akun akun yang dijelaskan sebagai berikut :

1. Aset

Kas dan setara kas yang disajikan dalam laporan posisi keuangan ini merupakan total atau jumlah dari aset bersih pada akhir tahun. Aset lancar untuk Madrasah Ibtidaiyah Baitul Makmur terdiri dari Kas Dana Bos dan juga Kas Infaq serta Aset Tetap, saldo aset tetap merupakan jumlah inventaris madrasah setelah dikurangi penyusutan.

2. Liabilitas dan Aset Neto

Nilai aset bersih terikat temporer dalam laporan posisi keuangan merupakan saldo akhir dari perhitungan sumbangan terikat dikurangi penggunaan biaya sesuai pembatasan. Sedangkan untuk nilai aset bersih tidak terikat merupakan hasil jumlah pendapatan dan peghasilan tidak terikat dikurangi jumlah beban dan pengeluaran Aset neto terikat permanen merupakan nilai inventaris Madrasah setelah dikurangi dengan akumulasi penyusutannya. 
Tabel 2 Laporan Aktivitas

Madrasah Ibtidaiyah Baitul Makmur Kota Kotamobagu

Laporan Aktivitas

Untuk Tahun Ajaran yang Berakhir pada 31 Juni 2016

(dalam jutaan rupiah)

PERUBAHAN ASET NETO TIDAK TERIKAT

\section{Pendapatan}

Pendapatan Dana Bos

168.221 .540

Pendapatan Komite

455.215 .000

Pendapatan Lain-Lain

2.740 .000

Jumlah

Aset Neto yang Berakhir Pembatasannya

(Catatan C):

Pemenuhan Program Pembatasan

626.176.540

Jumlah

Jumlah Pendapatan

78.835 .000

78.835 .000

Beban

Peng. Kompetensi Kelulusan

9.152 .000

Peng. Standar Isi

3.591 .500

Peng. Standar Proses

80.797 .550

Peng. Pendidik dan Tenaga Pendidik

453.229 .000

Peng. Sarana dan Prasarana Madrasah

33.505 .500

Peng. Standar Pengelolaan

2.184 .000

Peng. Standar Pembiayaan

32.592 .183

Peng. Dan Implementasi Sistem Penilaian

2.917 .500

Biaya Pembangunan

78.835 .000

Biaya Lain-Lain

20.140 .550

Jumlah

Penurunan Aset Neto Tidak Terikat

716.944.783

PERUBAHAN ASET NETO TERIKAT TEMPORER

(11.933.243)

Pendapatan Infaq-terikat temporer

93.870 .000

Aset Neto Terbebaskan Dari Pembatasan (Catatan C)

$(78.835 .000)$

Penurunan Aset Neto Terikat Temporer

15.035.000

PERUBAHAN ASET NETO TERIKAT PERMANEN

63.925.000

Inventaris Madrasah

(31.962.500)

Penyusutan

31.962.500

KENAIKAN ASET NETO

35.064.257

ASET NETO AWAL TAHUN

ASET NETO AKHIR TAHUN

35.064.257

Sumber: Data Olahan, 2016

Pada Tabel 2 terdapat akun-akun yang dapat dijelaskan sebagai berikut.

1. Pendapatan dan Penghasilan Tidak Terikat terdiri dari Pendapatan Dana BOS, Pendapatan Komite dan juga berasal dari pendapatan lain-lain.

2. Aset yang Dibebaskan dari Pembatasan merupakan total aset yang dikeluarkan untuk program pembatasan, nilai ini juga secara langsung merupakan jumlah aset yang pembatasannya telah berakhir karena telah digunakan untuk pemenuhan program yang telah dibatasi. 
3. Jumlah Pendapatan merupakan total dari penjumlahan jumlah aset yang telah berakhir pembatasannya dengan jumlah pendapatan dan penghasilan tidak terikat.

4. Beban. Yang termasuk dalam beban adalah semua penggunaan dana untuk membiayai program setiap bidang.

5. Pemenuhan Program Pembatasan. Dalam pemenuhan program pembatasan terdiri atas total sumbangan terikat, dan aset bersih yang terbebaskan dari pembatasan.

Tabel 3 Laporan Arus Kas

Madarasah Ibtidaiyah Baitul Makmur Kota Kotamobagu
Laporan Arus Kas

Arus Kas dari Aktivitas Operasi :

Kas dari Pendapatan Dana BOS

168.221 .540

Kas dari Pendapatan Komite 455.215 .000

Penerimaan lain-lain

Biaya Peng. Kompetensi Kelulusan

626.176.540

Biaya Peng. Standar Isi

9.152 .000

Biaya Peng. Standar Proses

3.591 .500

Biaya Pendidik dan Tenaga Pendidik

80.797 .550

Biaya Peng. Sarana dan Sarana Madrasah

453.229 .000

Biaya Peng. Standar Pengelolaan

33.505 .500

Biaya Peng. Standar Pembiayaan

2.184 .000

32.592 .183

Biaya Peng. Dan Implementasi Sistem Penilaian

2.917 .500

Biaya Lain-Lain

20.140 .550

(638.109.783)

Kas neto yang diterima (digunakan) untuk aktivitas operasi

(11.933.243)

\section{AKTIVITAS INVESTASI}

Penerimaan dari investasi

Kas bersih yang diterima (digunakan) untuk aktivitas investasi

AKTIVITAS PENDANAAN

Penerimaan dari kontribusi berbatas dari:

Pendapatan Infaq

Aktivitas Pendanaan Lain:

Biaya Pembangunan

78.835 .000

Kas neto yang digunakan untuk aktivitas pendanaan

15.035.000

KENAIKAN NETO DALAM KAS DAN SETARA KAS

3.101.757

KAS DAN SETARA KAS AWAL TAHUN

KAS DAN SETARA KAS AKHIR TAHUN

3.101.757

Sumber: Data Olahan, 2016

Penjelasan dari Laporan Arus Kas berdasarkan Tabel 3 adalah sebagai berikut.

1. Arus Kas dari Aktivitas Operasi. Akun-akun yang disajikan adalah penambahan dan pengurangan arus kas yang terjadi pada perkiraan yang terkait dengan operasional Madrasah seperti Kas dari Dana BOS, Kas dari Komite, Kas dari pendapatan lain-lain

2. Arus Kas dari Aktivitas Investasi. Dalam Aktivitas Investasi tidak ada saldo karena Madrasah Ibtidaiyah Baitul Makmur Kota Kotamobagu tidak melakukan aktivitas investasi 
3. Arus Kas dari Aktivitas Pendanaan. Perkiraan yang termasuk dalam aktivitas pendanaan adalah perkiraan penerimaan dari Infaq yang berasal dari orang tua siswa yang penggunaannya dibatasi untuk pelaksanaan pembangunan fisik Madrasah.

Tabel 4 Catatan Atas Laporan Keuangan

\section{Madrasah Ibtidaiyah Baitul Makmur Kota Kotamobagu \\ Catatan Atas Laporan Keuangan Tahun Ajaran 2015/2016 \\ (dalam Rp Juta)}

Catatan A menguraikan kebijakan Madrasah yang menyebabkan Catatan B dan C disajikan

\section{Catatan A}

\section{Pendirian}

Madrasah Ibtidaiyah Baitul Makmur Kota Kotamobagu adalah satuan pendidikan dasar formal setara dengan Sekolah Dasar (SD) yang menyelenggarakan kegiatan belajar-mengajar secara profesional dan akademik dibawah naungan Kementrian Agama . Madrasah Ibtidaiyah Baitul Makmur Kota Kotamobagu ini berdiri sejak 29 Juli 1998.

\section{Ikhtisar Kebijakan Akuntansi}

Dasar Laporan Penyusunan Akuntansi

Laporan dibuat sesuai Pernyataan Standar Akuntansi Keuangan (PSAK) No.45 Revisi 2011 tentang pelaporan keuangan untuk entitas nirlaba.

Laporan keuangan menurut PSAK 45 akan menyajikan jumlah masing-masing kelompok aset bersih berdasarkan ada tidaknya pembatasan oleh penyumbang, yaitu (1) terikat permanen, (2) terikat temporer dan (3) tidak terikat

Pembatasan yang bersifat permanen adalah pembatasan penggunaan sumber daya yang ditetapkan oleh penyumbang agar sumber daya tersebut dipertahankan secara permanen.

Pembatasan yang bersifat temporer adalah pembatasan penggunaan sumber daya oleh penyumbang yang menetapkan sumber daya tersebut dipertahankan untuk periode tertentu atau sampai dengan terpenuhinya keadaan tertentu.

Metode Arus Kas disusun dengan metode langsung dan mengelompokan arus kas kedalam kelompok aktivitas operasi, investasi dan pendanaan.

Madrasah Ibtidaiyah Baitul Makmur dalam aktivitasnya menyajikan aset netto terikat dalam 1 akun yaitu akun Kas Infaq. Kas infaq ini adalah sumbangan yang diperuntukkan untuk membiayai pembangunan fisik Madrasah. Jika kebutuhan untuk akun tersebut telah terpenuhi, maka dana tersebut dapat digunakan untuk pembiayaan aktivitas lain Madrasah. Apabila aset netto terikat tersebut tidak cukup membiayai kebutuhan biaya Pembangunan maka kebutuhan dana tersebut dipenuhi dengan sumbangan lainnya.

\section{Periode Akuntansi}

Periode Akuntansi mengacu padda siklus operasi normal Sekolah Dasar yang dimulai tanggal 1 Juli hingga 30 Juni

\section{Catatan B}

Seperti yang dijelaskan di awal bahwa Aset netto tidak terikat tidak mampu membiayai semua biaya operasi madrasah, sehingga pihak Madrasah menggunakan Aset netto terikat temporer untuk membiayai Biaya Pengembangan Pendidik dan Tenaga Pendidik sebesar Rp. 11.933.500

Pendapatan Kas Infaq

Biaya Pembangunan

78.835 .000

Biaya Peng. Pendidik dan tenaga Pendidik

11.933 .500

93.870.000

Total Aset Terikat

90.768.500

Belanja Lain-lain Madrasah

3.101 .500

0 


\section{Aset Neto Terikat Temporer \\ Catatan C}

3.101.500

Aset neto yang dibebaskan dari pemberi sumber daya yang tidak mengharapkan pembayaran kembali melalui terjadinya beban tertentu atau terjadinya kondisi yang diisyaratkan oleh pemberi sumber daya yang tidak mengharapkan pembayaran kembali:

Tujuan pembatasan yang dicapai:

Biaya Pembangunan

78.835 .000

Pembatasan yang telah terpenuhi

78.835.000

\section{Catatan D}

Aset tetap Madrasah disini merupakan semua inventaris yang berada dalam Madrasah dan digunakan untuk kegiatan operasional Madrasah dan bukan untuk diperjualbelikan. Aset teap Madrasah terdiri atas dua jenis, yaitu Aktiva tipe 1 yang merupakan inventaris yang berupa alat-alat elektronik dan Aktiva tipe 2 yang berupa barang-barang meubel. Untuk penyusutannya menggunakan metode garis lurus, dan Aktiva tipe 1 memiliki masa manfaat 4 tahun sedangkan aktiva tipe 2 memiliki masa manfaat 8 tahun.

\begin{tabular}{|l|l|l|l|l|}
\hline & JENIS & \multicolumn{1}{|c|}{ NILAI } & & \\
TAHUN & AKTIVA & AKTIVA & PENYUSUTAN & NILAI BUKU \\
\hline 2014 & \multirow{2}{*}{ AKTIVA } & $\mathrm{Rp} 46,300,000$ & $\mathrm{Rp} 11,575,000$ & $\mathrm{Rp} 34,725,000$ \\
\cline { 4 - 5 } & $\mathrm{Rp} 34,725,000$ & $\mathrm{Rp} 11,575,000$ & $\mathrm{Rp} 23,150,000$ \\
\cline { 4 - 5 } 2015 & TIPE I & $\mathrm{Rp} 23,150,000$ & $\mathrm{Rp} 11,575,000$ & $\mathrm{Rp} 11,575,000$ \\
\hline 2016 & & & Rp34,725,000 & \\
\hline TOTAL & & & &
\end{tabular}

\begin{tabular}{|c|c|c|c|c|}
\hline TAHUN & $\begin{array}{c}\text { JENIS } \\
\text { AKTIVA }\end{array}$ & $\begin{array}{c}\text { NILAI } \\
\text { AKTIVA }\end{array}$ & PENYUSUTAN & NILAI BUKU \\
\hline 2010 & \multirow{7}{*}{$\begin{array}{l}\text { AKTIVA } \\
\text { TIPE } 2\end{array}$} & Rp163,100,000 & Rp20,387,500 & Rp142,712,500 \\
\hline 2011 & & Rp142,712,500 & Rp20,387,500 & Rp122,325,000 \\
\hline 2012 & & Rp122,325,000 & Rp20,387,500 & Rp101,937,500 \\
\hline 2013 & & Rp101,937,500 & Rp20,387,500 & Rp81,550,000 \\
\hline 2014 & & Rp81,550,000 & Rp20,387,500 & Rp61,162,500 \\
\hline 2015 & & Rp61,162,500 & Rp20,387,500 & Rp40,775,000 \\
\hline 2016 & & Rp40,775,000 & Rp20,387,500 & Rp20,387,500 \\
\hline TOTAL & & & Rp142,712,500 & \\
\hline
\end{tabular}

Sumber: Data Olahan Tahun 2016

Catatan atas Laporan Keuangan Madrasah Ibtidaiyah berupa.

1. Kebijakan Madrasah Baitul Makmur Kota Kotamobagu.

2. Catatan Aset Bersih Terikat Temporer.

3. Catatan Aset Bersih yang Dibebaskan dari Pembatasan.

\subsection{Pembahasan}

Pencatatan Laporan Keuagan yang dibuat Madrasah Ibtidaiyah Baitul Makmur Kota Kotamobagu berdasarkan arahan pemilik yayasan. Dasar pencatatannya yaitu Bukti penerimaan kas berupa kartu iuran komite dan infaq untuk penerimaan dana BOS Yayasan menggunakan slip penarikan dari bank sebagai dasar pencatatan, untuk pengeluaran kas yang menjadi dasar pencatatan ialah kwitansi. Kemudian bukti transaksi ini diinput kedalam Laporan Kas Umum Madrasah. Kemudian akan dipergunakan untuk membuat Laporan 
Realisasi Anggaran untuk tahun berjalan. Madrasah juga memiliki daftar inventaris walau hanya mencantumkan nama inventaris dan jumlahnya, tanpa harga perolehan.

Masalah yang ditemukan dalam Laporan Keuangan Madrasah adalah masalah pengelompokkan transaksi. Pihak Madrasah belum mengelompokkan jenis akun dengan baik, selain itu Madrasah belum membuat penyusutan pada inventarisnya. Kemudian masih banyak terdapat salah catat dalam Buku Kas Umumnya.

Berdasarkan pada PSAK No. 45, sekilas terlihat lebih rumit dibandingkan dengan laporan keuangan Madrasah, tetapi Laporan Keuangan yang dihasilkan berdasarkan PSAK No.45 ini jelas memberikan hasil yang lebih relevan, dapat diandalkan dan dapat dibandingkan, karena lebih akurat sehingga akuntabilitas dari laporan keuangan itu sendiri lebih memadai dibandingkan menggunakan laporan keuangan yang dibuat Madrasah.

\section{KESIMPULAN DAN SARAN}

\subsection{Kesimpulan}

Laporan keuangan yang dibuat oleh Madrasah lebih sederhana, setiap kas masuk yang diperoleh dari Komite dan Dana BOS akan dicatat kedalam bukti kas setoran yang dipegang oleh pihak terkait yang bertanggungjawab dalam hal tersebut. Selain itu, ketika terjadi transaksi yang menyebabkan kas berkurang juga dibuatkan bukti kas keluar. Bukti kas setoran dan bukti kas keluar ini yang diinput kedalam laporan kas umum setiap minggunya, dan menjadi dasar pembuatan laporan realisasi anggaran untuk tahun berjalan. Penerapan PSAK no. 45 pada Madrasah akan menghasilkan laporan keuangan yang terdiri atas: Laporan Posisi Keuangan, Laporan Aktivitas, Laporan Arus Kas dan Catatan atas Laporan Keuangan. Standar ini terlihat lebih rumit tapi dengan menerapkan standar ini akan menghasilkan laporan keuangan yang lebih memadai.

\subsection{Saran}

1. Sebaiknya Madrasah Ibtidaiyah Baitul Makmur Kota Kotamobagu menerapkan PSAK No. 45 yaitu Neraca, Laporan Aktivitas, Laporan Arus Kas hingga Catatan Atas Laporan Keuangan sehingga Madrasah Ibtidaiyah Baitul Makmur Kota Kotamobagu memiliki laporan keuangan yang berkualitas.

2. Sebaiknya Madrasah Ibtidaiyah Baitul Makmur Kota Kotamobagu melakukan penilaian aset.

3. Untuk Aset Terikat Temporer sebaiknya hanya digunakan untuk membiayai program sesuai dengan tujuan pemberian sumbangan, tidak untuk memenuhi dana untuk program lainnya.

4. Sebaiknya Badan Komite Madrasah Ibtidaiyah Baitul Makmur mulai melakukan pelatihan dalam menerapkan PSAK No. 45 dalam penyajian laporan keuangannya.

\section{DAFTAR PUSTAKA}

Harahap, Sofyan Syafri.2011. Teori Akuntansi. Edisi Revisi 2011. Raja GrafindoPersada. Jakarta

Hasana, Kharisty. 2011. Ciri-Ciri Organisasi Nirlaba, Organisasi Nirlaba. Tanggalakses07Oktober2011http://kharistyhasanah.blogspot.com/2011/10/organisasinirlaba.html

Ikatan Akuntan Indonesia (IAI).2009. Pernyataan Standar Akuntansi Keuangan.Salemba Empat. Jakarta

Kuncoro, Mudrajad, 2009. Metode Riset Untuk Bisnis dan Ekonomi. Edisi Ketiga. Erlangga. Jakarta 
Mamesah, Melisa, 2013. Penerapan PSAK NO. 45 Pada GMIM Efrata Sentrum Sonder Kaitannya Dengan Kualitas Informasi Laporan Keuangan. Jurnal EMBA Vol. 1 No. 4. Diakses pada 20 September 2016

Pontoh, Winston, 2013. Akuntansi Konsep dan Aplikasi. Halaman Moeka. Jakarta.

Pontoh, Chenly Ribka S. 2013. Penerapan Penyusunan Laporan KeuanganOrganisasi Nirlaba Berdasarkan PSAK No. 45 Pada Gereja Bukit Zaitun LuwukSulawesi Tengah. Universitas Sam Ratulangi. Jurnal EMBA. Vol. 1 No.3. diakses pada 20 September 2016.

Reeve, James M., Warren, Carl S., Duchac, Jonathan E., Wahyuni, Ersa Tri., Soepriyanto, Gatot., Jusuf, Amir Abadi. \& Djakman, Chaerul D., 2009. Pengantar Akuntansi Adaptasi Indonesia. Salemba Empat. Jakarta.

Sugiyono.2010. Metode Penelitian Kuantitatif, Kualitatif Dan R\&D. Alfabeta. Bandung.

Sujarweni. 2015. Akuntansi Sektor Publik. Pustaka Baru Press. Yogyakarta 